\title{
Profesi Sebagai Guru
}

\author{
Muhammad Alian Noor \\ Email: 2010111310005@mhs.ulm.ac.id \\ Program Studi Pendidikan Sejarah Fakultas Keguruan dan Ilmu Pendidikan \\ Universitas Lambung Mangkurat \\ Banjarmasin
}

\begin{abstract}
Abstrak
Profesi secara etimologi berasal dari kata profession (Inggris) yang berasal dari bahasa Latin profesus yang bearti " mampu atau ahli dalam suatu bentuk pekerjaan". Profesi dapat diartikan sebagai suatu pekerjaan atau jabatan yang menuntut keahlian, yang didapat melalui pendidikan dan latihan tertentu, menurut persyaratan khusus memiliki tanggung jawab dan kode Etik tertentu. Pekerjaan yang bersifat profesional berbeda dengan pekerjaan lainnya karena suatu profesi memerlukan kemampuan dan keahlian khusus dalam melaksanakan profesinya. Profesi juga diartikan sebagai suatu jabatan atau pekerjaan tertentu yang mensyaratkan pengetahuan dan keterampilan khusus yang diperoleh dari pendidikan akademis yang intensif.
\end{abstract}

\section{PENDAHULUAN}

Profesi secara etimologi dari kata profession (Inggris) yang berasal dari bahasa Latin Profesus yang bearti "mampu atau ahli dalam suatu bentuk pekerjaan". Profesi dapat diartikan sebagai suatu pekerjaan atau jabatan yang menurut keahlian, yang didapat melalui pendidikan dan latihan tertentu, menurut persyaratan khusus memiliki tanggung jawab dan kode etik tertentu

(Susanto,H. 2020:13)

Profesi Guru berdasarkan UU RI No.14 tahun 2005 tentang guru dan dosen pasal 1, Guru adalah pendidikan profesional dengan tugas utama mendidik, mengajar, membimbing, mengarahkan, melatih, menilai, dan mengevaluasi peserta didik pada pendidikan anak usia dini jalur pendidikan formal, pendidikan dasar, dan pendidikan menengah. (Susanto, H. 2020:16)

\section{PERAN GURU SEBAGAI SEBUAH PROFESI}

Guru merupakan suatu profesi, yang bearti suatu jabatan yang memerlukan keahlian khusus sebagai guru dan tidak dapat dilakukan oleh orang sembarang orang diluar bidang pendidikan. Walaupun pada kenyataannya masih terdapat guru yang tidak memiliki latar belakang pendidikan bidang keguruan. (Susanto, H. 2020:17)

Berdasarkan UU RI No.14 tahun 2005 tentang guru dan dosen, guru adalah pendidikan profesional dengan tugas utama mendidik, mengajar, membimbing, mengarahkan, melatih, melatih, menilai, dan mengevaluasi peserta didik pada pendidikan 
anak usia dini jalur pendidikan formal, pendidikan dasar, dan pendidikan menengah. Dosen adalah pendidik profesional dan ilmuan dengan tugas utama mentransformasikan, mengembangkan, dan menyebarluaskan ilmu pengetahuan, teknologi, dan seni melalui pendidikan, penelitian, dan pengabdian kepada masyarakat. Menurut Noor Jamaluddin (1978:1) Guru adalah pendidik, yaitu orang dewasa yang bertanggung jawab memberi bimbingan atau bantuan kepada anak didik dalam perkembangan jasmani dan rohaninya agar mencapai kedewasaannya, mampu berdiri sendiri dapat melaksanakan tugasnya sebagai makhluk Allah khalifah di muka bumi, sebagai makhluk sosial dan individu yang sanggup berdiri sendiri. Sedangkan Rickey (1987) sebagaimana dikutif Soetjipto dan Kosasi (2009:17) mengemukakan ciri-ciri guru sebagai profesi, yaitu:

1) Adanya komitmen dari para guru bahwa jabatan itu mengharuskan pengikutnya mengungkung tinggi martabat kemanusiaan lebih dari pada mencari keuntungan diri sendiri.

2) Suatu profesi menyaratkan orangnya mengikuti persiapan profesional dalam jangka waktu tertentu.

3) Harus selalu menambah pengetahuan agar terus menerus berkembang dalam jabatannya.

4) Memiliki kode etik jabatan.

5) Memiliki kemampuan intelektual menjawab masalah-masalah yang dihadapi.

6) Selalu ingin belajar terus-menerus mengenai bidang keahlian yang ditekuni.

7) Menjadi anggota dari suatu organisasi profesi.

8) Jabatan itu dipandang sebagai suatu karir hidup. (Susanto, H. 2020:16-17)

\section{GURU INDONESIA DAN TANTANGAN PROFESIONALISME}

Profesionalisme diperlukan untuk memajukan pendidikan di negara Indonesia karena profesional mengandung makna yang berkualitas tinggi dalam hal teknis, kemampuan guru dalam beberapa bagian : kemampuan merencanakan pengajaran, kemampuan melaksanakan prosedur mengajar, kemampuan melaksanakan hubungan pribadi dengan siswa. Kemudian guru yang bersifat profesionalisme tentu memiliki keahlian dalam bidangnya seorang guru tentu saja tidak hanya menguasai materi pembelajaran yang diajarkan tetapi juga mampu dalam menanamkan konsep tentang pengetahuan yang diajarkannya, pemahaman konsep dapat dikuasai bidang guru memahami psikologi mengajar. Profesionalisme sangat diperlukan dalam memajukan pendidikan di Indonesia tentu juga sebagai perilaku kerja yang mengutamakan kesempurnaan hasil dengan menjalankan mekanisme kerja yang benar, hal ini sangat diperlukan untuk menunjang pendidikan Indonesia guru yang profesional berorientasi pada klien, dan menunaikan sikap tanggung jawab pada pekerjaan. (Susanto, H. 2020:56-60

Berkaitan dengan definisi kompetensi dan profesionalisme, setiap individu yang menjalankan profesi wajib memiliki kompetensi sesuai dengan bidang profesinya. Profesi 
guru dalam undang-undang No.14 tahun 2005 tentang guru dan dosen mengharuskan sebuah komponen pokok yang harus dimiliki seorang guru profesional, kompetensi tersebut adalah: kompetensi profesional, kompetensi pedagogik, kompetensi sosial, dan kompetensi kepribadian.

1. Kompetensi profesional guru

Kompetensi profesional guru berasal dari dua kata yaitu kompetensi dan profesional. Pengertian dasar kompetensi adalah kemampuan atau kecakapan. Dalam arti lain kompetensi profesional guru ialah kemampuan dan kewenangan guru dalam menjalankan profesi keguruannya, artinya guru yang dipiawai dalam melaksanakan profesinya dapat disebut sebagai guru yang kompeten dan profesional.

2. Kompetensi pedagogik guru

Pedagogik adalah teori mendidik yang mempersoalkan apa dan bagaimana mendidik sebaik baiknya. (Suardi, 1979:113) sedangkan menurut pengertian Yunani pedagogik adalah ilmu menuntun anak yang membicarakan masalah atau persoalanpersoalan dalam pendidikan dan kegiatan mendidik, tugas guru yang utama adalah mengajar dan mendidik murid dikelas maupun diluar kelas guru selalu berhadapan dengan murid yang memerlukan pengetahuan, keterampilan dan sikap utama untuk menghadapi hidupnya dimasa depan. Dilihat dari proses pembelajaran kompetensi pedagogik merupakan kemampuan guru dalam pengelolaan perkembangan pembelajaran peserta didik.

3. Kompetensi sosial guru

Merupakan kemampuan guru untuk memahami dirinya sebagai bagian dari masyarakat dan mampu mengembangkan tugas sebagai anggota masyarakat dan warga negara (Satori dkk, 2008:215) dengan memahami dan menerapkan nilai dan norma yang berlaku dimasyarakat karena guru merupakan bagian dari masyarakat, selain itu dalam hal memenuhi tanggung jawab sebagai pengajar guru harus bisa mencerdaskan masyarakat sebagai mana yang diatur, dalam pembukaan undangundang dasar negara Republik Indonesia pada alinea keempat. Berkomunikasi lisan dan tertulis, menggunakan teknologi informasi komunikasi secara fungsional, bergaul secara aktif dengan peserta didik, sesama pendidik, tenaga pendidikan, orang tua atau wali murid, serta bergaul secara santun dengan masyarakat sekitarnya.

4. Kompetensi kepribadian guru

Merupakan salah satu jenis kompetensi yang diperlu dikuasai seorang guru selain 3 jenis kompetensi lainnya: sosial, pedagogik dan profesional. Dalam penjelasan peraturan pemerintah No.19 tahun 2005 tentang standar nasional pendidikan disebutkan bahwa kompetensi kepribadian guru yaitu kepribadian yang mantap, stabil, dewasa, Arif dan bijaksana, berwibawa, berakhlak mulia dan 
mengembangkan diri secara berkelanjutan sementara itu menurut pemendiknas No.16 tahun 2007 tentang kualifikasi dan kompetensi guru menjelaskan kompetesi kepribadian untuk guru wali kelas dan guru mata pelajaran pada semua jenjang, pendidikan dasar hingga menengah. (Amirudin, konsep, pendidik: 80-84)

\section{SIMPULAN}

Profesi secara etimologi berasal dari kata proession (Inggris) yang berasal dari bahasa Latin profesus yang bearti "mampu atau ahli dalam suatu bentuk pekerjaan". Profesi dapat diartikan sebagai suatu pekerjaan atau jabatan yang menurut keahlian yang didapat melalui pendidikan dan latihan tertentu, menurut persyaratan khusus memiliki tanggung jawab dan kode etik tertentu. Pekerjaan yang bersifat profesional berbeda dengan pekerjaan yang lainnya karena suatu profesi memerlukan kemampuan dan keahlian khusus dalam melaksanakan profesinya. Profesi juga diartikan sebagai suatu jabatan atau pekerjaan tertentu yang mensyaratkan pengetahuan dan keterampilan khusus yang diperoleh dari pendidikan akademis yang intensif. Jadi profesi adalah suatu pekerjaan atau jabatan yang menuntut keahlian tertentu. Artinya suatu pekerjaan atau jabatan yang disebut profesi tidak dapat dipegang oleh sembarangan orang, tetapi memerlukan persiapan melalui pendidikan dan pelatihan secara khusus. Bedasarkan UU RI No.14 tahun 2005 tentang guru dan dosen pasal 1, Guru adalah pendidik profesional dengan tugas utama mendidik, mengajar,membimbing,mengarahkan,melatih, menilai, dan mengevaluasi peserta didik pada pendidikan anak usia dini jalur pendidikan formal, pendidikan dasar, pendidikan menengah.

\section{REFERENSI}

Efendi, I., Prawitasari, M., \& Susanto, H. (2021). Implementasi Penilaian Pembelajaran Pada Kurikulum 2013 Mata Pelajaran Sejarah. Prabayaksa: Journal of History Education, 1(1), 21-25.

Susanto, H. (2020). Profesi Keguruan. Banjarmasin: FKIP Universitas Lambung Mangkurat.

Susanto, H., \& Akmal, H. (2018). Efektivitas Penggunaan Aplikasi Pembelajaran Berbasis Mobile Smartphone Sebagai Media Pengenalan Sejarah Lokal Masa Revolusi Fisik Di Kalimantan Selatan Pada Siswa Sekolah Menengah Atas. HISTORIA: Jurnal Program Studi Pendidikan Sejarah, 6(2), 197-206.

Susanto, H., Irmawati, I., Akmal, H., \& Abbas, E. W. (2021). Media Film Dokumenter Masuknya Islam Ke Nusantara dan Pengaruhnya Terhadap Keterampilan Berpikir Kritis Siswa. HISTORIA: Jurnal Program Studi Pendidikan Sejarah, 9(1).

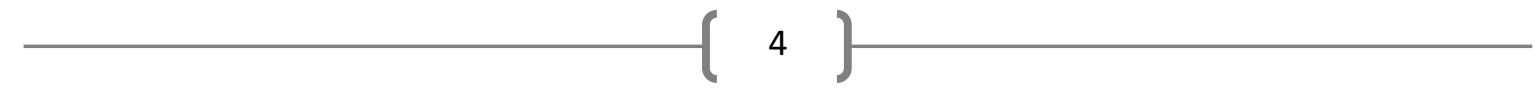


Syaharuddin, S., \& Susanto, H. (2019). Sejarah Pendidikan Indonesia (Era Pra Kolonialisme Nusantara sampai Reformasi). Banjarmasin: FKIP Universitas Lambung Mangkurat. 